\title{
Outcomes of Integrated Community Care Interventions for Frail Elderly People: A Literature Review
}

\author{
Junko Imaiso \\ School of Nursing and Graduate School of Nursing, University of Shizuoka, Shizuoka, Japan \\ Email: junko@u-shizuoka-ken.ac.jp
}

How to cite this paper: Imaiso, J. (2018) Outcomes of Integrated Community Care Interventions for Frail Elderly People: A Literature Review. Health, 10, 1120-1131. https://doi.org/10.4236/health.2018.108085

Received: July 20, 2018

Accepted: August 27, 2018

Published: August 30, 2018

Copyright $\odot 2018$ by author and Scientific Research Publishing Inc. This work is licensed under the Creative Commons Attribution-NonCommercial International License (CC BY-NC 4.0). http://creativecommons.org/licenses/by-nc/4.0/ (c) (i) \& Open Access

\begin{abstract}
This study aimed to summarize the outcome measures and the significant outcome of effective integrated community care for frail elderly people through a literature review. A literature search was conducted using the Cochrane Library and PubMed for articles published up to November 2016 with the following search terms: Integrated community care, primary care, community, frail elderly, and effectiveness. A total of 106 articles were identified, of which eight with an interventional research design the inclusion criteria. All outcome measures were classified into the three categories: Functional abilities, quality of life, and health. As the significant effect, the physical function was perceived in four references, the quality of life in one reference, and the mental health in one reference. The evidence of the effectiveness of integrated community care seemed to be lacking. More studies will need to be conducted.
\end{abstract}

\section{Keywords}

Integrated Community Care, Primary Care, Effectiveness, Frail Elderly, Global

\section{Introduction}

Japan faces the challenge of a super-aging society with the world's highest percentage of elderly people aged $\geq 65$ years (27.3\% in 2016), and the percentage is estimated to increase even further due to decreasing birth rates and increasing longevity [1]. Globally, the proportion of people aged $\geq 65$ years is also on the rise, leading to a greater worldwide interest in and awareness of long-term home-based care [2]. Indeed, aging and super-aging populations have become 
global concerns.

The possibility of requiring care increases with age, and frail elderly people aged $\geq 75$ years who have complex acute and chronic medical problems, as well as functional disabilities, comprise a particularly vulnerable group. However, care for frail elderly people has been characterized as being fragmented and lacking overall responsibility and accountability, and associated with negative incentives [3]. Thus, an effective community care system including medical facilities needs to be developed for frail elderly people. In particular, effective community care for elderly people will require integration of medical care and caregiving based on multidisciplinary collaborations. Integrated health systems include community-based and community-focused services that are oriented toward primary health care and health promotion, and provide the basis for additional secondary and specialty services [4]. As such, effective primary health care including primary care will become a key element in developing effective integrated community care. Primary care, which refers to first-contact, continuous, comprehensive, coordinated, family-centered, and community-oriented care, regardless of gender, disease, or the affected organ system [5], will thus lead to improved community health. In 2008, the World Health Organization advocated that primary care systems be strengthened in all countries, urging the promotion of primary care as an approach to provide effective, fair, and efficient care [6].

In Japan, care needs among the elderly are expected to increase as baby boomers (born between 1947 and 1949) reach the age of 75 years or older in 2025. As we face social changes in the near future, Draft Act on Amendatory Law to the Related Acts for Securing Comprehensive Medical and Long-Term Care in the Community came into effect in 2014 [1]. The purpose of this law is to promote the integration of medical care and long-term care in community caregiving services. In order to provide uniform community services pertaining to housing, medical treatment, caregiving, prevention (including primary, secondary, and tertiary), and support in daily life across the country, the Japanese Ministry of Health, Labour and Welfare proposed that an integrated community care system be established in each community by 2025 , considering the characteristics of the each community. This system will not only allow elderly people to continue living in their homes until the end of their lives, but also help to address many social issues including a further population decline associated with aging, decreasing proportions of children, changes in family composition, increasing single elderly individuals, aging of elderly caregivers, and prevalence of dementia in patients as well as their elderly caregivers. Among the academia in Japan, the need to develop a systematic community strategy for improving the quality of life (QOL) of the elderly has been suggested [7]. Particularly, QOL is the key goal for health promotion in older people [8].

Community care innovations for frail elderly people will be expected in order to prevent their worse health state, and thus, it will be important to construct an 
effective integrated community care system focused on frail elderly people through an evaluation of their effectiveness. It is suggested that many frail older adults are seen by healthcare professionals in primary care, and that integrated care programs have been developed to enhance the quality of care in the setting [9]. In considering how effective integrated community care should be constructed for the frail elderly, evaluation items and outcomes of such care need to be clarified, and related findings be accumulated.

This study aimed to summarize the outcome measures of effective integrated community care for frail elderly people and to perceive the significant outcome of the effect in each research paper through a literature review of studies with an interventional research design.

\section{Methods}

An electronic search was performed using the Cochrane Library and PubMed for English articles published in peer-reviewed journals up to November 2016 with the following search terms: integrated community care, primary care, community, frail elderly, and effectiveness. In each database, the combinations of the search terms were two patterns as follows; 1 ) integrated community care and frail elderly and effectiveness; 2) primary care and community and frail elderly and effectiveness.

Identified articles were screened on the basis of title and abstract, and selected articles were subjected to full-text assessment and critical review according to the following inclusion criteria: studies in which a practice-based integrated community care intervention was performed for frail elderly people, with outcomes relating to the effect of integrated community care relevant to frail elderly people regardless of disease. Integrated community care was defined as community-based primary care based on an elderly-focused or elderly-centered model designed to meet the needs of frail elderly people.

Outcome measures were categorized through collecting the similar kind of elements which were used in the method of each research. And, significant effective measure was clarified based on the outcomes of each research paper.

\section{Results}

A total of 106 articles were identified by the electronic search, of which 22 were selected on the basis of title and abstract. Among these, eight articles met the inclusion criteria after a critical review of the full text and were included in the analysis (Figure 1).

Table 1 summarizes data extracted from the eight studies. Five studies were published in 2016, and the remaining three were published in 2004, 2008, and 2013. Except for one study conducted in Canada, studies were conducted in the Netherlands. Study locations were not described enough to identify the characteristics of the community. Four studies used a randomized controlled trial (RCT) design [10] [11] [12] [13], one used a non-RCT design [14], and three 
Table 1. Overview of data extracted from the included studies.

\begin{tabular}{|c|c|c|c|c|c|c|}
\hline Reference & Study Design & Participants & Aim & $\begin{array}{c}\text { Study } \\
\text { Location }\end{array}$ & $\begin{array}{c}\text { Intervention and } \\
\text { Control }\end{array}$ & Outcomes \\
\hline $\begin{array}{c}\text { Tourigny A, et } \\
\text { al., } 2004\end{array}$ & $\begin{array}{l}\text { Quasi } \\
\text {-experimental } \\
\text { study (analyzed } \\
\text { changes before } \\
\text { intervention [T0] } \\
\text { and every } 12 \\
\text { months [T1, T2, } \\
\text { T3] after } \\
\text { intervention for a } \\
\text { 3-year period) }\end{array}$ & $\begin{array}{l}482 \text { frail elderly } \\
\text { people aged } \geq 75 \text { years } \\
\text { and their } \\
\text { caregivers from } 2 \\
\text { semi-urban } \\
\text { communities ( } 272 \\
\text { elderly people and } 135 \\
\text { caregivers in the } \\
\text { experimental group; } \\
210 \text { and } 129 \text { in the } \\
\text { control group) }\end{array}$ & $\begin{array}{l}\text { To determine the } \\
\text { impact of the } \\
\text { Integrated Service } \\
\text { Delivery (ISD) } \\
\text { network on frail } \\
\text { elderly people and } \\
\text { their caregivers, and } \\
\text { on the utilization of } \\
\text { health and social } \\
\text { services }\end{array}$ & $\begin{array}{l}\text { Bois-Frances } \\
\text { region in the } \\
\text { Province of } \\
\text { Quebec, } \\
\text { Canada }\end{array}$ & $\begin{array}{l}\text { ISD implemented } \\
\text { study area versus } \\
\text { no-ISD control area }\end{array}$ & $\begin{array}{l}\text { "Outcomes in frail } \\
\text { elderly people" } \\
\text { 1) Positive effects on } \\
\text { desire to be } \\
\text { institutionalized in the } \\
\text { first two years (T0 - T1: } \mathrm{P} \\
=0.002 \text {, T0-T2: } \mathrm{P}=0.04) \\
\text { 2) Positive effects on } \\
\text { elderly people with } \\
\text { mobility problems at T1 } \\
(\mathrm{P}=0.002) \text { and T2 }(\mathrm{P}= \\
0.07) \\
\text { "Outcomes in caregivers" } \\
\text { Positive effects on } \\
\text { caregiver burden at T1 }(\mathrm{P} \\
=0.05) \text { and } \mathrm{T} 2(\mathrm{P}=0.04)\end{array}$ \\
\hline $\begin{array}{c}\text { Melis R, et al., } \\
2008\end{array}$ & $\begin{array}{l}\text { Pseudocluster } \\
\text { randomized } \\
\text { controlled trial } \\
\text { (RCT) (analyzed } \\
\text { differences } \\
\text { between } \\
\text { Intervention and } \\
\text { Control groups in } \\
\text { changes from } \\
\text { baseline in } \\
\text { GARS-3 and } \\
\text { MOS-20 MH at } \\
\text { 3-month } \\
\text { follow-up [T1 - } \\
\text { T0]) }\end{array}$ & $\begin{array}{l}151 \text { vulnerable } \\
\text { (problem-based) } \\
\text { elderly people aged } \geq \\
70 \text { years ( } 85 \\
\text { participants in the } \\
\text { DGIP group and } 66 \text { in } \\
\text { the usual care group) }\end{array}$ & $\begin{array}{l}\text { To describe the effects } \\
\text { of the Duch Geriatric } \\
\text { Intervention Program } \\
\text { (DGIP) compared to } \\
\text { usual care in } \\
\text { improving } \\
\text { health-related quality } \\
\text { of life and promoting } \\
\text { successful aging in } \\
\text { independently living } \\
\text { frail older patients }\end{array}$ & $\begin{array}{l}\text { Nijmegen, } \\
\text { The } \\
\text { Netherlands }\end{array}$ & $\begin{array}{l}\text { DGIP implemented } \\
\text { group and usual } \\
\text { care group }\end{array}$ & $\begin{array}{l}\text { "Primary outcome" } \\
\text { 1) Functional } \\
\text { performance improved } \\
\text { after } 3 \text { months of } \\
\text { follow-up from baseline } \\
(95 \% \mathrm{CI}=-4.2 \text { to }-0.3, \mathrm{p} \\
<0.05) \\
\text { 2) Mental well-being } \\
\text { improved after } 3 \text { months } \\
\text { of follow-up from } \\
\text { baseline (95\% CI }=0.1 \text { to } \\
11.4, \mathrm{p}<0.05) \\
3 \text { ) Mental well-being } \\
\text { improved after } 6 \text { months } \\
\text { of follow-up from } \\
\text { baseline (95\% CI = } 2.4 \text { to } \\
15.6, \mathrm{p}<0.01) \\
\text { "Secondary outcomes" } \\
\text { Negative affect domain of } \\
\text { DQoL improved at } 3 \\
\text { months ( } 95 \% \text { CI = -0.37 } \\
\text { to -0.04, p }<0.05 \text { ) }\end{array}$ \\
\hline $\begin{array}{l}\text { Metzelthin S, } \\
\text { et al., } 2013\end{array}$ & $\begin{array}{l}\text { Cluster RCT } \\
\text { (analyzed } \\
\text { differences at } \\
\text { baseline and at 6-, } \\
12-\text {-, and } \\
\text { 24-month } \\
\text { follow-up) }\end{array}$ & $\begin{array}{l}346 \text { frail elderly } \\
\text { people (Groningen } \\
\text { Frailty Indicator } \\
\text { scores } \geq 5 \text { ) aged } \geq 70 \\
\text { years in } 12 \text { general } \\
\text { practices ( } 193 \text { in the } \\
\text { intervention group [ } 6 \\
\text { practices] and } 153 \text { in } \\
\text { the control group) }\end{array}$ & $\begin{array}{l}\text { To investigate the } \\
\text { effectiveness of the } \\
\text { Prevention of Care } \\
\text { (PoC) approach on } \\
\text { various patient-level } \\
\text { outcomes compared } \\
\text { with usual care }\end{array}$ & $\begin{array}{l}\text { Sittard, The } \\
\text { Netherlands }\end{array}$ & $\begin{array}{l}\text { PoC implemented } \\
\text { group and usual } \\
\text { care group }\end{array}$ & $\begin{array}{l}\text { "Primary outcome" } \\
\text { No significant group by } \\
\text { time interaction effects for } \\
\text { the Groningen Activity } \\
\text { Restriction Scale scores or } \\
\text { for activities of daily living } \\
\text { and instrumental activities } \\
\text { of daily living subscale } \\
\text { scores } \\
\text { "Secondary outcomes" } \\
\text { No significant effects on } \\
\text { depressive } \\
\text { symptomatology, social } \\
\text { support interactions, fear } \\
\text { of falling, and social } \\
\text { participation }\end{array}$ \\
\hline
\end{tabular}




\section{Continued}

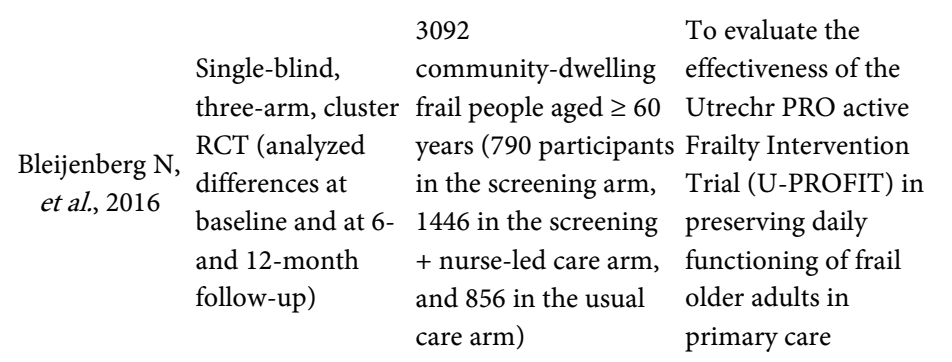

Matched

quasi

-experimental

Dijk H, et al., study (analyzed 2016

differences at

baseline and at 6and 12-month

follow-up)

\section{2}

community-dwelling frail older people aged $\geq 70$ years (186 in the intervention group group) and 186 in the control of Integrated Neighborhood Approaches (INAs) on health-related quality of life and well-being in frail older people
Utrecht, The Netherlands primary care
Intervention arm 1: Frailty screening followed by routine care from a general practitioner Intervention arm 2: Frailty screening followed by personalized nurse-led care Control arm
"Primary outcome"

1) No differences in mean Katz-15 scores among the three groups after 6 months

2) Less decline in daily functioning in both intervention groups compared to the control group $(95 \% \mathrm{CI}=1.77$ to 1.97, $\mathrm{P}=0.03)$ after 12 months

3) Significantly better preservation of daily functioning in more highly educated participants in the screening and nurse-led care group compared to all participants in the screening and control groups $(95 \% \mathrm{CI}=1.80$ to $1.96, \mathrm{P}=0.03$ )

"Secondary outcomes" 1) No significant differences among the three groups with respect to quality of life and satisfaction with care at 6or 12-month follow-up 2) No significant differences in the number of hospital admissions, number of emergency department visits, or mortality

No substantial differences
Rotterdam,

The

Netherlands in well-being or health related quality of life between the intervention and control groups at 1 year. 


$\begin{array}{rlll} & \begin{array}{l}\text { 24-month stepped } \\ \text { wedge cluster }\end{array} & 1147 & \\ \text { RCT (analyzed } & \begin{array}{l}\text { community-dwelling } \\ \text { older adults aged } \geq 65\end{array} & \begin{array}{l}\text { To evaluate the } \\ \text { impact of the }\end{array} \\ \text { Hoogendijk E, } & \text { differences } & \text { years (456 in group 1, } & \begin{array}{l}\text { Geriatric Care Model } \\ \text { et al., 2016) } \\ \text { between }\end{array} \\ \begin{array}{ll}\text { allocation groups } \\ \text { at baseline and at } \\ \text { every six months) }\end{array} & \begin{array}{l}\text { group 3, and 226 in } \\ \text { group 4) }\end{array} & \begin{array}{l}\text { life and several other } \\ \text { patient outcomes }\end{array} \\ & & \end{array}$

Quasi-

experimental

Looman W, et study (analyzed al., 2016 baseline and at 3 and 12-month follow-up)
503 frail older participants aged $\geq 75$ years (254 in the experimental group and 249 in the control group)
Two-arm cluster non-RCT

Ruikes F, et al., 2016

differences at (analyzed

baseline and at

12-month

follow-up)
536

community-dwelling frail elderly people aged $\geq 70$ years ( 287 in the intervention group and 249 in the control group)
To explore the effectiveness of the Walcheren Integrated Care Model (WICM) by evaluating the effects on health outcomes (experimental health, Rotterdam,

mental health, social The functioning), functional abilities, and quality of life (general, health-related, and well-being) in community-dwelling frail older people

To evaluate the effectiveness of a general practitioner-led extensive, multicomponent program (CareWell primary care program) integrating cure, care, and welfare for the prevention of functional decline

Netherlands
Amsterdam and WestDriesland, The Netherlands

implemented group and usual care group

Nijmegen,
Netherlands
months) group and usual care group
Group 1: 6 months No significant differences after initiation of between the GCM and GCM intervention usual care groups in and usual care SF-12. (baseline) "Secondary outcomes" Group 2: 12 months Significant intervention after initiation of effect on IADL limitations GCM intervention in patients who received and usual care the intervention for 18 (baseline and 6 months $(\mathrm{B}=-0.25,95 \%$ months) $\quad \mathrm{CI}=-0.43$ to $-0.06, \mathrm{P}=$ Group 3: 18 months 0.007$)$. However, this after initiation of effect was not significant GCM intervention after correcting for and usual care multiple comparisons (baseline, 6 and 12 No significant months) intervention effects on Group 4: 24 months EuroQoL, ADL after initiation of limitations, psychological GCM intervention well-being, self-rated and usual care health, and social (baseline, 6 months, functioning 12 months and 18 No significant effects on total and acute hospital admissions

Moderate significant effect on quality of life after 12 months $(95 \% \mathrm{CI}=-0.15$ to $5.63, \mathrm{p}<0.10)$

No effects on health related quality of life or well-being, although WICM impacted one dimension of well-being; the ability to receive love and friendship $(95 \% \mathrm{CI}=$ 0.14 to $0.36, \mathrm{p}<0.001)$. No significant differences between the groups in terms of experienced health, mental health, and social functioning

"Primary outcome" No significant differences between groups in independence in

CareWell Primary functioning during Care implemented activities of daily living "Secondary outcomes" No significant differences between groups in quality of life, institutionalization, hospitalization, and mortality 


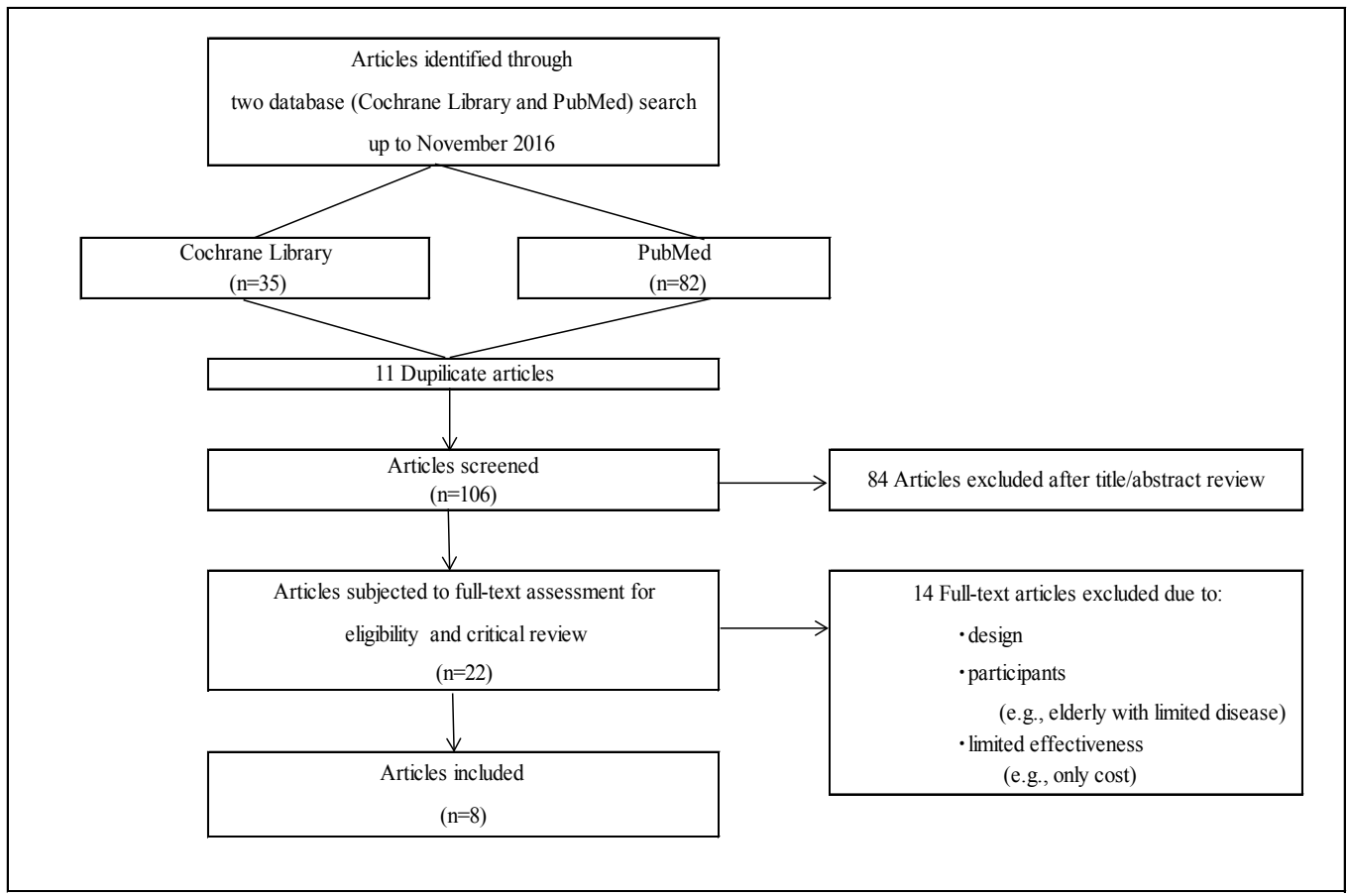

Figure 1. Flowchart of literature search.

used a quasi-experimental design [15] [16] [17]. In general, interventions were described thoroughly enough to allow for judgement as to whether they could be characterized as "integrated community care" or not. On the other hand, descriptions of the control group (often referred to as "usual care") generally lacked details, and differences between "integrated community care" and "other care" were unclear. The length of follow-up from baseline in these studies ranged from 3 to 36 months.

The number of participants in each study ranged from 151 to 3,092. Participants were problem-based elderly populations in all studies, and the criteria of frail individuals were described in seven studies [10] [11] [12] [13] [14] [16] [17]. One study [15] examined both frail elderly people and their caregivers. The age of participants was $\geq 70$ years in four studies [10] [11] [14] [16], $\geq 75$ years in two studies [15] [17], and $\geq 65$ years and $\geq 60$ years in the remain two studies [12] [13].

Outcome measures for the effectiveness of the integrated community care were classified into the following three categories: "functional abilities", "quality of life (QOL)", and "health". And, the statistical significant outcome of the effective integrated community care for frail elderly was perceived in each reference (Table 2).

\subsection{Functional Abilities}

Functional abilities included two elements: physical function and social function. The physical function was perceived as the significant effect in four references (Table 2). 
Table 2. Overview of the outcome of effective integrated community care for frail elderly.

\begin{tabular}{|c|c|c|c|c|c|}
\hline \multirow[t]{2}{*}{ Outcome Measure } & \multicolumn{2}{|c|}{ Functional Ability } & \multirow[b]{2}{*}{ QOL } & \multicolumn{2}{|c|}{ Health } \\
\hline & $\begin{array}{l}\text { Physical } \\
\text { Function }\end{array}$ & $\begin{array}{c}\text { Social } \\
\text { Function }\end{array}$ & & $\begin{array}{c}\text { Physical } \\
\text { Health }\end{array}$ & $\begin{array}{l}\text { Mental } \\
\text { Health }\end{array}$ \\
\hline Tourigny A, et al., 2004 & S & & & & \\
\hline Melis R, et al., 2008 & S & & S & & S \\
\hline Metzelthin S, et al., 2013 & NS & NS & & & \\
\hline Bleijenberg N, et al., 2016 & $S$ & & NS & NS & \\
\hline Dijk H, et al., 2016 & NS & & NS & & NS \\
\hline Hoogendijk E, et al., 2016 & $S$ & & NS & NS & NS \\
\hline Looman W, et al., 2016 & NS & NS & NS & NS & NS \\
\hline Ruikes F, et al., 2016 & NS & & NS & NS & \\
\hline
\end{tabular}

Note. $S=$ Significant, NS=Not Significant.

Physical function was defined as function during activities of daily living, mobility, or ability to perform instrumental activities of daily living (IADL). Physical function was used as an outcome measure in all studies, and in which primary outcome was four [10] [11] [12] [14] and secondary outcome was one [17].

Effects on physical function were observed in four studies [10] [12] [13] [15]. Tourigny et al. [15] reported that a significant positive effect was observed in elderly people with mobility problems at $12(\mathrm{P}=0.002)$ and $24(\mathrm{P}=0.04)$ months post-intervention in a quasi-experimental study. Melis et al. [10] observed significantly improved functional abilities (primary outcome) in the intervention group after three months in a pseudocluster RCT (95\% confidence interval [CI] $=-4.2$ to $-0.3, \mathrm{p}<0.05)$. Bleijenberg et al. [12] reported that the intervention group had significantly less decline in daily functioning (primary outcome) compared to the control group ( $95 \% \mathrm{CI}=1.77$ to $1.97, \mathrm{P}=0.03$ ) after 12 months in a cluster RCT. Hoogendijk et al. [13] reported that a significant intervention effect on IADL limitations was observed in frail elderly people who received the intervention for 18 months $(95 \% \mathrm{CI}=-0.43$ to $-0.06, \mathrm{P}=0.007$ ) in a stepped wedge cluster RCT. However, Metzelthin et al. [11] and Ruikes et al. [14] reported no significant changes in physical function.

Social function, or social participation in two studies [11] [17] was reported to show no significant changes.

\subsection{QOL}

Six studies [10] [12] [13] [14] [16] [17] used QOL as an outcome measure. The QOL was perceived as the significant effect in one reference (Table 2).

Although QOL was the primary outcome in one [13] of the six studies, no significant positive change was reported. Another study [10] measured QOL as a secondary outcome and reported a significant effect after three months, relative to baseline ( $95 \% \mathrm{CI}=-0.37$ to $-0.04, \mathrm{p}<0.05)$. Other studies [12] [14] [16] [17] found no significant effect on QOL. 


\subsection{Health}

Health included both physical and mental elements. The mental health was perceived as the significant effect in one reference (Table 2).

Physical health was related to hospitalization, mortality, hospital admission, or number of emergency department visits. Four studies [12] [13] [14] [17] used physical health as an outcome measure. However, none of these studies reported significant effects of the interventions on physical health.

Mental health reflected mental well-being or psychological well-being. Among four studies [10] [13] [16] [17] that used mental health as an outcome measure, one study [10] assessed mental well-being as the primary outcome and reported that a significant improvement was observed in the intervention group after three $(95 \% \mathrm{CI}=0.1$ to $11.4, \mathrm{p}<0.05)$ and six $(95 \% \mathrm{CI}=2.4$ to $15.6, \mathrm{p}<0.01)$ months of intervention in a pseudocluster RCT. The other three studies [13] [16] [17] reported no significant effects on mental health.

\section{Discussion}

The Japanese government is currently promoting the construction of an integrated community care system in each community by 2025 in order to address changes associated with the increasing elderly population and decreasing birth rates. It is important to consider how an effective integrated community care system should be constructed, and what aspects of evaluation need to be focused on. In the present study, a literature review of eight interventional studies was carried out with the aim of summarizing the outcome measures and the significant outcome of effective integrated community care for frail elderly people in each research paper.

In the eight research papers, except for one study conducted in Canada, studies were conducted in the Netherlands. It is said that in the Netherlands, strong primary care system is constructed and that there are various integrated care models in communities. It is suggested that the Netherlands was the highest volume publisher per 10,000 researchers from primary care, followed the United Kingdom, and that the Netherlands seem to rapidly increase its productivity in primary care research [18]. Therefore, it seemed that the most of the eight research papers might be in the Netherlands.

Among the three categories of outcome measures (functional abilities, QOL, and health), integrated community care seemed to be effective in improving functional abilities of frail elderly people. In particular, positive effects on physical function have been reported although social function was reported to show no significant change. QOL as an outcome measure was used in six studies and positive significant effect was showed in one study [10]. Physical health as an outcome measure was used in four studies [12] [13] [14] [17] and mental health was used in four studies [10] [13] [16] [17]. But, the significant improvement in the mental health was showed in one study [10].

In one study [10], integrated community care had significant effects on all of 
the three categories of outcome measures; physical function, mental health, and dementia QOL (DQoL), although only the "negative affect" domain of DQoL showed significant improvement. Moreover, although an effect on mental health was observed after three and six months relative to baseline, the effects on physical function and DQoL were significant only after three months in that study.

Through the literature review in the present study, the evidence for the effectiveness of the integrated community care for the frail elderly seemed to be lacking. It is said that critical evaluation of the available evidence is difficult due to the heterogeneity of so-called "community intervention models" [10]. Indeed, "community" is a diverse concept. On the other hand, aging and super-aging populations are global concerns. Therefore, it will be important to explore how to construct an effective integrated community care system focused on the elderly people considering an evaluation of their effectiveness worldwide. Through the present study, it was suggested that studies pertaining to effective integrated community care were published relatively recently, with roughly $62 \%$ of identified research papers published in 2016. It seemed to be recent. Further studies will need to be conducted.

In the further studies, it may be better that the inclusion criteria of the frail elderly in the baseline may be set up clearer enough to perceive the positive effects of intervention in a longer study period. And, about the outcome measure of effective integrated community care for frail elderly, it was seemed that social aspect such as social function or social participation need to be more focused on, considering the character of community environments such as urban or rural. It is suggested that non-medical solutions such as social care, community services and the voluntary sector should have a larger role within integrated care programs [9]. The eight research papers in the present study primarily involved interventions carried out by healthcare professionals. The research design which several interventions are compared within the same study will need to be considered in order to find effective combinations of components of integrated community care for the frail elderly. And also, it will be more important to pile the research data globally and perform meta analysis.

\section{Acknowledgements}

A part of the manuscript was presented as Scientific Peer-Reviewed Poster at the 44the Biennial Convention in Sigma Theta Tau International, Oct. 28-Nov. 1, 2017.

\section{Conflicts of Interest}

None declared.

\section{References}

[1] Health and Welfare Statistics Association (2017) Kokumin eisei no doukou [Tendency about People's Health]. Journal of Health and Welfare Statistics, 64, 49, 190. 
[2] Genet, N., Boerma, W., Kringos, D., et al. (2011) Home Care in Europe: A Systematic Literature Review. BMC Health Services Research, 11, 1-14.

https://doi.org/10.1186/1472-6963-11-207

[3] Bergman, H., Béland, F., Lebel, P., et al. (1997) Care for Canada's Frail Elderly Population: Fragmentation or Integration? Canadian Medical Association Journal, 157, 1116-1121.

[4] Messias, D.H. (2001) Globalization, Nursing, and Health for All. Journal of Nursing Scholarship, 33, 9-11. https://doi.org/10.1111/j.1547-5069.2001.00009.x

[5] Starfield, B. (1994) Is Primary Care Essential? Lancet, 344, 1129-1133. https://doi.org/10.1016/S0140-6736(94)90634-3

[6] The World Health Organization (2008) The World Health Report 2008: Primary Health Care Now More than Ever. Geneva, Swizerland.

[7] Konishi, M. (2015) Koureisha ga anshin shite kurasu kenkou komyunityi wo mezashite [Systematic Strategy of the Community for Improving the Quality of Life of the Elderly]. Gakujyutsu no Doukou [Trends in the Sciences], 20, 59.

[8] Lee, T.W., Ko, I.S. and Lee, K.J. (2006) Health Promotion Behaviors and Quality of Life among Community-Dwelling Elderly in Korea: A Cross-Sectional Survey. International Journal of Nursing Studies, 43, 293-300.

https://doi.org/10.1016/j.ijnurstu.2005.06.009

[9] Hoogendijk, E. (2016) How Effective Is Integrated Care for Community-Dwelling Frail Older People? The Case of the Netherlands. Age and Aging, 45, 587-590. https://doi.org/10.1093/ageing/afw081

[10] Melis, R., Eijken, M., Teerenstra, S., Achterberg, T., Parker, S., Borm, G., et al. (2008) A Randomized Study of a Multidisciplinary Program to Intervene on Geriatric Syndromes in Vulnerable Older People Who Live at Home (Dutch EASY Care Study). Journal of Gerontology: Medical Sciences, 63, 283-290.

https://doi.org/10.1093/gerona/63.3.283

[11] Metzelthin, S., Rossum, E., Witte, L., Ambergen, A., Hobma, S., Sipers, W., et al. (2013) Effectiveness of Interdisciplinary Primary Care Approach to Reduce Disability in Community Dwelling Frail Older People: Cluster Randomised Controlled Trial. BMJ, 347, f5264. http://dx.doi.org/10.1136/bmj.f5264

[12] Bleijenberg, N., Drubbel, I., Schuurmans, M., Dam, H., Zuithoff, N., Numans, M., et al. (2016) Effectiveness of a Proactive Primary Care Program on Preserving Daily Functioning of Older People: A Cluster Randomized Controlled Trial. Journal of American Geriarics Society, 64, 1779-1788. https://doi.org/10.1111/jgs.14325

[13] Hoogendijk, E., Horst, H., Ven, P., Twisk, J., Deeg, D., Frijters, D., et al. (2016) Effectiveness of Geriatrics Care Model for Frail Older Adults in Primary Care: Results from a Stepped Wedge Cluster Randomized Trial. European Journal of Internal Medicine, 28, 43-51. https://doi.org/10.1016/j.ejim.2015.10.023

[14] Ruikes, F., Zuidema, S., Akkermans, R., Assendelft, W., Schers, H. and Koopmans, R. (2016) Multicomponent Program to Reduce Functional Decline in Frail Elderly People: A Cluster Controlled Trial. The Journal of the American Board of Family Medicine, 29, 209-217. https://doi.org/10.3122/jabfm.2016.02.150214

[15] Tourigny, A., Durand, P., Bonin, L., Hébert, R. and Rochette, L. (2004) Quasi-Experimental Study of the Effectiveness of an Integrated Service Delivery Network for the Frail Elderly. Canadian Journal on Aging, 23, 231-246.

https://doi.org/10.1353/cja.2004.0038

[16] Dijk, H., Cramm, J., Birnie, E. and Nieboer, A. (2016) Effects of an Integrated 
Neighborhood Approach on Older People's (Health-Related) Quality of Life and Well-Being. BMC Research Notes, 9, 1-10.

[17] Looman, W., Fabbricotti, I., Kuyper, R. and Huijsman, R. (2016) The Effects of a Pro-Active Integrated Care Intervention for Frail Community-Dwelling Older People: A Quasi-Experimental Study with the GP-Practice as Single Entry Point. BMC Geriatrics, 16, 1-10. https://doi.org/10.1186/s12877-016-0214-5

[18] Glanville, J., Kendrick, T., McNally, R., Campbell, J. and Hobbs, R. (2011) Research Output on Primary Care in Australia, Canada, Germany, the Netherlands, the United Kingdom, and the United States: Bibliometric Analysis. BMJ, 342, d1028. https://doi.org/10.1136/bmj.d1028 